\section{Hükümet Sistemleri ve Özgürlük: Karşılaştırmalı Bir İnceleme}

Government Systems and Freedom: A Comparative Analysis

\section{Hamza ATEŞ ${ }^{1}$}

\section{Aydın AKPINAR ${ }^{2}$}

Strategic Public Management Journal

Volume 3, Issue 6, pp. 1-22

DOI: $10.25069 /$ spmj.344204

Received: 14.10.2017

Accepted: 27.12.2017

(C) The Author(s) 2017

For reprints and permissions: http://dergipark.gov.tr/spmj

$\ddot{O}_{z}$

Bu makalenin amacı bir takım ortak değerlerin oluşturduğu benzer hükümet sistemlerine sahip dünya üzerindeki ülkeleri belirli kategoriler altında toplayarak kısmen objektif bir ölçüt niteliği taşıyan Freedom House 'un 2016 verilerine göre hükümet sistemlerinin 'özgürlük’ boyutuna değerlendirmelerde bulunmaktır.

Bu çalışmada coğrafi, tarihi ve kültürel gibi bir takım ortak paydaya sahip ülkeler hükümet sistemleri baz alınıp kategorize edilerek karşılaştırmalı olarak incelenecektir. Oluşturulan bu kategorilerin Freedom House'un belirlemiş olduğu puanlar üzerinden ortalaması alınarak hükümet sistemlerin özgürlüğü ne ölçüde etkilediği ortaya konmaya çalışllacaktır. Bu çalı̧̧ma ile Türkiye ve Türkiye gibi yeni hükümet sistemi tartışmaları ve yeni bir hükümet sistemi arayışı olan ülkelere 'Daha fazla özgürlük için hangi hükümet sistemi?' sorusuna yanit aranacaktır. Oluşturulan kategorilerin kapsamını bir hükümet sistemine sahip tüm dünya ülkeleri oluşturacaktır. Oluşturulan ve yorumlanan bu kategoriler üzerinden Türkiye'de akademik literatürde pek yer bulamamış olan hükümet sistemi tartışmalarının özgürlük boyutu değerlendirilmiş olacaktır.

Anahtar Kelimeler: Freedom House, Hükümet Sistemleri, Türkiye, Karşılaştırmalı Siyaset, Özgürlük.

\begin{abstract}
The main purpose of this article is to assess the 'freedom' dimension of government systems according to Freedom House's 2016 data, which collects some of the world's countries with similar government systems, which are formed by a number of common values, into certain categories, with an objective criterion.

In this study, countries with common geographical, historical and cultural characteristics will be categorized and examined comparatively based on government systems. These categories will be averaged over the points that Freedom House has determined, and it will be tried to show how much government systems affect freedom. This study will also shed light into the debate in such countries as Turkey, which seek a more appropriate government system, through finding an evidence based response to the question of "What kind of government is needed for greater freedom?". In this way, the paper will contribute to academic literature on government systems particularly presidency and parliamentary system debate by evaluating the relationship between
\end{abstract}

\footnotetext{
${ }^{1}$ Prof. Dr., İstanbul Medeniyet Üniversitesi, Siyasal Bilgiler Fakültesi Siyaset Bilimi ve Kamu Yönetimi Bölümü, hamza.ates@medeniyet.edu.tr

2 Arş. Gör., Marmara Üniversitesi, Siyasal Bilgiler Fakültesi, Yerel Yönetimler Bölümü, aydin.akpinar@marmara.edu.tr
} 
government systems and freedom, which is considered as an important but neglected dimension of the search for a new government system in Turkey.

Key words: Freedom House, Governance Systems, Turkey, Comparative Politics, Freedom.

\section{GíRiş}

Türk Dili Kurumu tarafından özgürlük, 'herhangi bir kısıtlamaya, zorlamaya bağlı olmaksızın düşünme veya davranma, herhangi bir şarta bağlı olmama durumu' olarak tanımlanmıştır (Türk Dil Kurumu, 2016). Toplumlar zamanla, kişinin doğuştan elde ettiği en temel haklarını oluşturan bu durum ve davranışları güvence altına almak adına tarihle birlikte evirilen bir takım süreçten geçmiştir. Bu sürecin başlangıcını ideal bir devlet modeli sunan Platon'un Devlet adlı eseri ve yine Platon'un dönemindeki diğer filozoflar ve hocalarının görüşleriyle oluşan devlet felsefesine kadar dayandırmak mümkündür. Sağlıklı ve mutlu bir toplum hayatı oluşturmak adına geliştiren kuram ve düşünceler geliştirilmeye devam etmiş, Thomas Hobbes ve Jean-Jacques Rousseau gibi tarihin önemli filozofları tarafından açıklanan toplumsal sözleşme kuramı ile somut bir düzenin temelleri atılmaya başlamıştır. Bu uzun aralıkta inen dinlerden ateşkes anlaşmalarına kadar geniş kitleleri ilgilendiren birçok gelişme yine sağlıklı ve mutlu bir toplum hayatı oluşturmak adına günümüz seviyesi için bir basamak niteliği taşımaktadır.

Temelleri atılan somut düzen tarih içerisinde yavaş yavaş şekillenmeye başlamış, siyaset sosyolojisini geliştiren Montesquieu, farklı toplumlardaki farklı pozitif hukuk sistemlerinin halkın karakteri, ekonomik koşulları, iklimi gibi çeşitli değişkenlere dayalı olduğunu dile getirmiştir. Yine Montesquieu, siyaset ve hukuk konusunda tümevarımcı ve deneysel bir yaklaşım benimsemiş, olguları kaydetmek yerine anlamayı, yaşanan gelişmeleri konu alan karşılaştırmalı, tarihsel gelişmeler ışığında sistematik bir araştırmanın temellerini atmıştır. Bu görüşü ve tekniği ışığında 'Kanunların Ruhu' adlı kitabını yazmış, siyaset literatürüne önemli bir eser kazandırmıştır. $\mathrm{Bu}$ eserinde yönetim tarzlarını birbirinden ayırmış, kuvvetler ayrılığı esasını ortaya atmış aynı zamanda günümüz hükümet sistemlerinin iskeletini oluşturan yasama, yürütme ve yargı organlarının ayrıllı̆ının üzerinde durmuştur. $\mathrm{Bu}$ dönemde Anglo-Sakson ülkelerinin hükümet gelenekleri ve bu geleneklerden esinlenerek oluşturulan hükümet kurumları günümüz hükümet sistemlerinin saf halini oluşturmaya başlamıştır. $\mathrm{Bu}$ hükümet sistemleri ülkelerin coğrafi, ekonomik ve kültürel gibi değişkenlere bağlı olarak gelişmiş ve şekillendirilmiştir.

İnsanlığın varoluşundan bu yana özgürlük, insan hayatında ve toplumda önemli bir mesele olarak yerini korumuştur. Günümüzde ise özgürlügün temin edilmesinde hükümet sistemleri önemli bir yer teşkil etmektedir. Bir devletin yönetim şekli olan hükümet sistemi o toplumu oluşturan bireylerin özgürlükleri için bir bekçi niteliğindedir.

Günümüzde ve tarihte hükümet sistemlerinin Freedom House'un baz aldığı insan hakları, sivil toplum, ifade özgürlüğü, basın özgürlüğü gibi haklar ve özgürlüklerin üzerindeki etkisi azımsanamayacak bir ölçüdedir. Devlet içindeki 'insan odaklı' yönetim anlayışı, azınlık hakları, temsilde adalet, haberleşme özgürlüğü gibi dünya gündeminde daha fazla yer almaya başlayan ve demokrasi ile sıkı bir bağ 1 olan bu olguların mevcut yönetim sisteminde yer bulması kaçınılmaz olmuştur.

Bağımsız bir sivil toplum örgütü olan ve verileri birçok karşılaştırmalı siyaset çalışmasında kullanılan Freedom House, ülkeleri siyasal haklar ve sivil haklar gibi kriterlerin 1'den 100'e kadar bir puan aralığında derecelendirilmesi ile oluşan 3 sınıf altında toplamaktadır: Özgür, Kısmen Özgür ve Özgür Değil. Yine bu ülkeler 1 ila 7 arasında sivil haklar, sivil özgürlük ve basın özgürlüğü üzerinden değerlendirilmektedir.

Çalışmada hükümet sistemleri üzerine yapılan çalışmalar irdelendikten sonra, karşılaştırmalı siyaset literatüründe önemli bir yere sahip olan Freedom House hakkında genel bilgiler sunulacak, Freedom House'un çalışma konuları ortaya konulacaktır. Bu çerçevede bir takım ortak değerlerin oluşturduğu benzer hükümet 
sistemlerine sahip dünya üzerindeki kategorilendirilmiş belirli ülkeleri, ülkelerdeki mevcut hükümet sistemleri başlığı altında açıklayarak hükümet sistemleri ve özgürlük arasındaki ilişkiyi bir takım sayısal veriler eşliğinde açıklanmaya çalışılacaktır. Hükümet sistemlerine kategorilendirilmiş ülkeler ve Freedom House'un yayınlamış olduğu özgürlük verileri üzerinden elde edilen bulgular değerlendirilecek ve çalışmanın sonunda son yıllarda yoğun bir gündeme sahip hükümet sistemi tartışmalarına, literatürde çok fazla yer alamamış olan özgürlük üzerinden değerlendirmelerde bulunulacaktır. Bu çalışmadaki veriler Freedom House'un 2016 y1lı raporundaki verilerinden faydalanılarak elde edilmiştir.

\section{LITERATÜR TARAMASI}

Demokrasi, hükümet sistemleri tartışmaları, siyasi istikrar, temsilde adalet gibi özgürlük ve hükümet sistemlerinin arasında bulunan konular yüzyıllardır tartışılan ve tartışılmaya ihtiyaç duyulan konular olarak literatürde nicelik ve nitelik olarak iyi bir noktadır. Ancak özgürlük ve hükümet sistemleri her ne kadar birbirleri ile oldukça derin ve ciddi bir ilişkiye sahip olsa da yazında tam olarak iki kavramı temel alan bir çalışmadan söz etmek oldukça zordur.

Giovanni Sartori (1997), Shugart ve Carey (1992), Linz (1994; 1995), Lijphart (1999), Siaroff (2003), Hamilton (1992), Wilson (1992) ve Roskin (2009) gibi alanında saygın siyaset bilimcilerinin başkanlık sistemi, parlamenter sistem, yarı-başkanlık sistemi modellerinin tanımlanması ve temel unsurlarını, sistemlerin avantajları ve dezavantajlarını, sistemin yol açtığı sorunların boyutlarını anlama noktasında geniş bir bilgi ve perspektif sunmaktadır. Hükümet sistemlerinin yanı sıra özgürlük boyutuna Freedom House'un uzun yıllardır yayınlamış olduğu yıllık, bölgesel, ülkesel ve yerel boyutlardaki ayrıntılı raporları dünyada özgürlüğün ne durumda olduğunu detaylı bir şekilde gözler önüne sermektedir. Freedom House'un yanı sıra 1994 yılında Colorado Üniversitesinde 157 ülkeyi yaklaşık iki asırlık bir aralıkta inceleyen Polity III: Regime Type and Political Authority raporu ülkelerin demokrasi seviyeleri hakkında önemli veriler sunmaktadır.

Robert Dahl'ın "kendisi konuyla ilgili yazına hayret verici hâkimiyeti yanında, kıyaslanamaz ölçüdeki verileri bir araya getirmiş...” yorumunda bulunduğu Arend Lijphart tarafından kaleme alınan Demokrasiler kitabının genişletilmiş ve güncellenmiş hali Demokrasi Motifleri: Otuz Altı Ülkede Yönetim Biçimleri ve Performansları adlı eser hangi demokrasinin daha iyi işlediğine dair önemli bir perspektif sunmaktadır. Freedom House tarafından yayımlanan raporların da kullanıldığı bu çalışmada otuz altı çağdaş demokrasinin parti sistemleri, seçim sistemleri, anayasaları, yönetim sistemleri, nüfusları, ekonomik durumları ve Merkez Bankaları detaylı bir şekilde incelenerek çoğunlukçu demokrasilerden ziyade uzlaşmacı demokrasilerin daha fazla özgürlük vaat ettiği sonucunu vermektedir. Hem sunduğu geniş bilgiler hem de çalışmamıza yapısal olarak yakınlığı noktasında bu çalışma önemli bir yere sahiptir.

Çağdaş siyaset biliminin ve düşüncesinin önde gelen teorisyenlerinden Robert Dahl Demokrasi Üzerine adlı eserinde üzerinde tam olarak bir uzlaşma sağlanamamış 'demokrasi nedir?' sorusuna açık ve özlü bir şekilde yanıt vermektedir. Özgürlüğün olmazsa olmazlarından ideal demokrasiyi, iyi bir demokrasinin ihtiyacı olduğu kurumlarını ve demokrasinin getirilerini ortaya koyan çalışma demokrasi kökenlerinden ele almış ve hala tamamlanmamış bir yolculuk olduğu sonucuna varmış, daha fazla özgürlük ve demokrasinin gerekliliklerini tartışmıştır.

Siyaset bilimci Samuel Hungtinton tarafından 1996 yılında kaleme alınan yine saygın Türk siyaset bilimci Ergun Özbudun tarafından çevrilen Üçüncü Dalga: Yirminci Yüzyılın Sonlarında Demokratlaşma adlı eser hem teorik hem de tarihsel bir nitelik taşımaktadır. Hungtinton dünyadaki demokratikleşme dönemlerini sistematik bir şekilde incelemiş, üçüncü dalga demokrasi olarak nitelendirdiği 1970'li yıllarda demokratikleşme sürecine giren ülkeleri ekonomik gelişmeler, dinsel faktörler, dış aktörler, siyasi liderlik gibi değişkenlerle inceleyerek dünyada özgürlük ve demokrasi adına önemli bir dönemi ortaya koymuştur. 
2013 yılında Haluk Alkan tarafından kaleme alınan Karşılaştırmalı Siyaset: Başkanlık ve Parlamenter Sistemler Iş̧̆ğında Yarl-Başkanlık Sistemi isimli eser, başkanlık, yarı-başkanlık ve parlamenter sistem modellerini teorik olarak örnekleri üzerinden açıklarken modellerin olumlu ve olumsuz taraflarını tartışmakta ve Türkiye genelinde uygulanabilirliğini tartışmaktadır. Çalışma 2007 yılında yapılan Anayasa değişikliği sonrası cereyan eden tartışmalar sonucu Türkiye hükümet sisteminin niteliği üzerinden, tartışmaya konu olan sistem benzeri ülkeler üzerinden değerlendirmelerde bulunulmuştur. Çalışma özellikle üçüncü bölümünde Avrupa'daki yarı-başkanlık modellerini inceleyerek parlamenter sistem olarak bilinen modellerin ötesine geçip hem geniş bir perspektif kazandıran hem de çalışmada kimi ülkelerin hükümet sistemini isim olarak değil de işleyiş olarak hangi model olduğunu ortaya koyan veriler sunmaktadır. Sistem içerisindeki yetki genişliğinin hükümet sistemi modelini nasıl etkilediğini ortaya koymaktadır.

Serap Yazıcı, Başkanlık ve Yarı-Başkanlık Sistemleri: Türkiye İçin Bir Değerlendirme adlı çalışmasında başkanlık sistemlerinin tanımını yaptıktan sonra bu sistemlerin dayandıkları temel unsurları ve bu unsurların yol açtığı sorunları tartışıyor. Daha sonra başkanlık yönetimi ile parlamenter yönetimin bazı unsurlarını birleştiren bir ara hükümet modeli olarak tanımlanabilen yarı-başkanlık sistemini ele alıyor. Ancak bu teorik tartışmaların öncesinde çalışmanın girişinde sunmuş olduğu sayısal veriler ve kategorilendirilmiş ülkeler teorik bilgiler öncesinde geniş bir perspektifle beraber çalışmamıza paralel veriler sunmaktadır.

\section{BAĞIMSIZ BİR GÖZLEM ÖRGÜTÜ: FREEDOM HOUSE}

'75 yıldır demokrasinin bekçisi' sloganıyla Freedom House, kendisini dünya çapında özgürlügün ve demokrasinin yayılmasına adamış bağımsız bir gözlemci organizasyondur. 1941 yılında kurulan ve ilk Amerikan küresel özgürlüğü geliştirme şampiyonu olan kuruluşun, özgürlüğün önündeki engelleri analiz etmek, daha fazla siyasal hakları ve sivil özgürlügü savunmak, demokratik değişimi teşvik etmek ve insan haklarını savunmak için eylemcileri desteklemek gibi misyonlar edinmiştir.

Freedom House'un şu an 14 adet ofisi bulunmaktadır ve dünyada, toplam 30 ülkede program yürütmektedir. Örgütün başlıca finansmanları gelişmemiş ve gelişmekte olan ülkelere ekonomik ve insanı yardımlarda bulunan The United States Agency for International Development (USAID) ve ABD Dışişleri Bakanlığı'dır.

Organizasyon, Latin Amerika, Güneydoğu Asya gibi bölgesel, Tunus, Azerbaycan ve Uganda'da İfade Özgürlügü gibi ülkesel ve LGBTI hakları gibi grupsal programlarının yanı sıra her yıl 'Dünyada Özgürlük' adlı oldukça ayrıntılı bir rapor hazırlamaktadır. Örgütün sunduğu bu rapor yayınlandığı yıldaki çarpıcı gelişmeleri özetleyen bir başlık altında yayınlar. (Örneğin 2016 yılı için "Endişeli Diktatörler, Kararsız Demokrasiler: Baskı Altındaki Küresel Özgürlük” başlığı kullanılmıştır.) Raporda demokrasinin metodolojisinden bahsedildikten sonra yayınlandığı yıla göre ülkeler üzerinde genel değerlendirilmelerde bulunur ve yine yayınlandığ yılın kayda değer gelişmeleri ortaya konulur. Sayısal verilerle desteklenen raporda, dünyadaki ve bölgelerdeki eğilimler nüfustan özgürlük derecelerine kadar ayrıntılı istatistiklerle sunulmaktadır. Raporun sonunda ise 1 ila 7 arasında ( 1 en iyi, 7 en kötü olmak üzere) her ülkenin siyasal haklar ve sivil özgürlükleri puanlanır. Daha sonra 1 ila 100 arasında (100 en iyi, 1 en kötü olmak üzere) yine her ülke için bir toplam puan belirlenir. Bu puanlara göre ülkelerin özgürlük statüsü belirlenir: Özgür, Kısmen Özgür, Özgür Değil. Yine sunulan tabloda geçmiş yıllara göre gelişmeleri belirtmek için artan ve azalan puanlar belirtilir, 2015 yılının özgürlük statüleri paylaşılır.

\section{HÜKÜMET SISTEMLERİ ve ÖZGÜRLÜK ARAŞTIRMASI}

$\mathrm{Bu}$ araştırmanın amacı, bir takım ortak değerlerin oluşturduğu benzer hükümet sistemlerine sahip dünya üzerindeki ülkeleri belirli kategoriler altında toplayarak kısmen objektif bir ölçüt niteliği taşıyan Freedom House'un 2016 verilerine göre hükümet sistemlerinin 'özgürlük' boyutuna değerlendirmelerde bulunmaktır. $\mathrm{Bu}$ değerlendirmeler sayesinde hükümet sistemlerinin ‘özgürlük' üzerinde ne ölçüde etkili olduğu ortaya 
koymaya çalışılacak ve daha önce hükümet sistemleri tartışmalarında doğrudan incelenmemiş bir boyut ele alınarak literatüre önemli bir katkı sağlanacaktır. Özünde 'Daha fazla özgürlük için nasıl bir hükümet sistemi?' sorusuna yanıt arayan bu araştırma yeni bir hükümet sistemi arayışında olan Türkiye, dünya ülkeleri ve bu ülkelerin akademik dünyası için bir rehber niteliği kazanacaktır.

Dünya üzerinde Freedom House tarafindan değerlendirilen 195 ülkenin hükümet sistemleri ve Freedom House'un yayınlamış olduğu özgürlük kriterleri bu araştırmanın kapsamını oluşturmaktadır. Dünya üzerindeki bağımsızlığı tartışmalı ülkeler ve bölgeler bu araştırmaya dâhil edilmeyecektir.

$\mathrm{Bu}$ araştırmada nicel araştırma yöntemlerinden kendi koşulları içerisinde olduğu gibi tanımlamaya çalışan model olarak betimlenen, tarama modeli kullanılacaktır. Mevcut taramalardan elde edilen veriler 1şında betimleyici ve yorumlayıcı yaklaşım, araştırmanın yöntemini oluşturacaktır.

Araştırmada öncelikle ülkeler hükümet sistemlerine göre sınıflandırılacak bu sınıflar içerisinde kategorilendirilecektir. Bu kategoriler mevcut hükümet sisteminin başlığ 1 altında yorumlanacak ve çalışmanın sonunda genel değerlendirmelerde ve Türkiye adına bir değerlendirmede bulunulacaktır.

Araştırma tüm dünya ülkelerini kapsadığı ve birçok türevi olan hükümet sistemlerini konu edindiği için birtakım kısıtlılıklara sahiptir. Öncelikle dünya üzerinde birebir aynı hükümet sistemlerine rastlamak neredeyse imkânsızdır. Kimi ülkeler mevcut hükümet sisteminin özünü büyük ölçüde korurken kimisi literatürde yeni bir hükümet sistemi olarak nitelendirilebilecek ölçüde değişikliklere uğramıştır. Bu noktada hükümet sistemleri sınırlandırılırken ülkedeki mevcut kimi sistem ve kurumlardan dolayı başka bir hükümet sistemine de dâhil etmek mümkün olabilir. Araştırmada ülkeler, hükümet sisteminin saf halini edinmiş şekilde kategorilendirilecektir. Bunun yanı sıra araştırmanın üzerine kurulacağı Freedom House verileri her ne kadar uzun yıllar boyunca bağımsız bir örgüt olarak nitelendirilen bir örgüt tarafından yayınlanmış olsa da ABD menşeli ve fonlarının büyük ölçüde ABD'nin kimi resmi kurumları tarafından sağlayan bir kuruluş olmasından dolayı duygusal olarak değerlendirilmiş bir takım istatistiklerle de karşılaşılabilmek mümkündür.

\section{BULGULAR}

1776 yılında Amerikan Bağımsızlık Bildirgesi’nin yazarları, Bildirgede şu sözlere yer vermiştir:

"Bütün insanların eşit yaratıldıklarına, Yaratıcıları tarafindan onlara Hayat, Özgürlük ve Mutluluğunu Arama hakkı gibi geri alınamaz bazı haklar verildiğine inanıyoruz."

Robert Dahl (2010) Demokrasi Üzerine adlı çalışmasına bu sözleri aktarırken eşitliğin önemi üzerinde durmuş, eşitlik ilkesini benimseyen bir yönetim sistemi nasıl yaratılabilir sorusuna cevap bulmaya çalışmıştır (Dahl, 2010:73-75). Birden fazla boyuta sahip olan bu sözü Dahl, eşitlik üzerinden ele alırken bizler 'özgürlük' üzerinden ele alacağız. Özgürlüğün, hayat ve mutluluğu arama hakkının yanı sıra geri alınamaz haklardan biri olduğu sözde vurgulanmıştır. Ancak bu hakların ne ölçüde kullanılabildiği önemli bir konudur ve bu noktada hükümet sistemleri ön plana çıkan unsurlardan biridir.

\subsection{Parlamenter Monarşi}

Parlamenter monarşi diğer bir adıyla Westminster Modeli, parlamenter rejimlerin kökeni niteliğindedir. $\mathrm{Bu}$ model, en büyük temsilcisi İngiltere'de doğmuş ve gelişerek İngiltere'nin çevresine (Kuzey Amerika ve Kuzeybatı Avrupa) yayılmış aynı zamanda eski sömürgesi altında bulunan ülkelere (Okyanusya ve Güneydoğu Asya) modelin kurumları ve gelenekleri devredilmiştir (Alkan, 2013:77). Parlamenter Monarşi, siyasal bir güce sahip monarşik bir iktidar ile gelişmekte olan temsili demokrasinin gereklilikleri olan siyasal kurumların orta bir noktada buluşması sonucu doğmuştur. Nihayetinde Parlamenter Monarşi, monarkın yetkilerinin bir anayasa tarafından sınırlandırıldığı yönetim şekli olarak tanımlanabilir (Teziç, 1998). 
Siyaset Bilimci Arend Lijphart, Demokrasi Motifleri adlı eserinde Parlamenter Monarşi modelini şu ayırt edici özellikleriyle açıklamıştır: i) yasama ve yürütme organlarında etkin bir güce sahip olması ve aynı zamanda Avam Kamarasına karşı sorumlu bir başbakana sahip olması, ii) model içerisindeki monark, yasama ve yürütme organlarının dengeleyici bir sisteme sahip olması ve bundan dolayı her ne kadar koalisyon hükümetlerine rastlanmasa da uzlaşmacı bir ortam yaratması, iii) başbakanın sistem içerisinde belirleyici olması, iv) hükümetin görevde kalmasını sağlayacak parlamentonun güvenoyuna ihtiyacı olması, v) disiplinli ancak demokrasiyi engellemeyen iki parti sistemine dayalı bir model olması, vi) seçim sisteminin 'dar bölge çoğunluk sistemi' olmas1, vii) üniter bir devlet yapısına sahip olması, viii) esnek anayasal devlet yapısına sahip olmas1, ix) büyük ölçüde hükümetin kontrolünde olan bir Merkez Bankası'nın varlığı (Karasu, 2009; Eroğul, 2012; Lijphart, 2006; Alkan, 2013).

Alkan'ın (2013) da belirttiği gibi mevcut açıklamalar yalnızca geleneksel parlamenter monarşi sistemini açıklamaktadır. Bugün dünya üzerinde birebir benzer iki hükümet sistemine rastlamak neredeyse imkânsızdır. Hükümet sistemleri mevcut bulunduğu ülkelerin gelenekleri, kültürleri, coğrafi konumu gibi etkenlerle özünde aynı olsa da yapısında birçok farklı1ık mevcut olabilmektedir. Bu noktada ele alacağımız parlamenter monarşi modelleri geleneksel modelin özelliklerini taşısa da bir o kadar da değişime uğramış bir yapıya sahiptir.

Tablo 1. Parlamenter Monarşi ile Yönetilen Ülkeler ve Kategorileri

\begin{tabular}{|c|c|c|c|c|c|c|c|}
\hline \multicolumn{4}{|c|}{ Kategori } & \multicolumn{2}{|c|}{ Ülke Sayısı } & \multicolumn{2}{|c|}{ Ortalama Özgürlük Puanı } \\
\hline \multicolumn{4}{|c|}{ Amerika } & \multicolumn{2}{|c|}{9} & \multicolumn{2}{|c|}{91} \\
\hline \multicolumn{2}{|c|}{ Orta Amerika 1} & \multicolumn{2}{|c|}{ Kanada } & 8 & 1 & 90 & 99 \\
\hline \multicolumn{4}{|c|}{ Avrupa } & \multicolumn{2}{|c|}{9} & \multicolumn{2}{|c|}{97} \\
\hline Kuzеу Avrupa & \multicolumn{2}{|c|}{ Güney ve Batı Avrupa } & $B K$ & 3 & 1 & \multicolumn{2}{|l|}{99} \\
\hline \multicolumn{4}{|c|}{ Asya-Pasifik } & \multicolumn{2}{|c|}{4} & \multicolumn{2}{|c|}{97} \\
\hline \multicolumn{2}{|c|}{ Asya-Pasifik 1} & \multicolumn{2}{|c|}{ Japonya } & 3 & 1 & 97 & 96 \\
\hline \multicolumn{4}{|c|}{ Diğer } & \multicolumn{2}{|c|}{7} & \multicolumn{2}{|c|}{54} \\
\hline Asya-Pasifik 2 & \multicolumn{2}{|c|}{ Orta Amerika 2} & Lesoto & 3 & 1 & 36 & 67 \\
\hline \multicolumn{4}{|c|}{ Yarı Parlamenter Monarşi } & \multicolumn{2}{|c|}{7} & \multicolumn{2}{|c|}{52} \\
\hline \multicolumn{2}{|c|}{ Yart-Parlamenter 1} & \multicolumn{2}{|c|}{ Yart-Parlamenter 2} & 2 & 5 & 93 & 36 \\
\hline
\end{tabular}

Parlamenter monarşi ile yönetilen ülkelerin sistemlerini özgürlük üzerinden değerlendirirken 5 ana 12 alt kategori halinde ele alınacaktır. Bu 12 kategori içerisinde 36 ülke bulunmakta olup dünya nüfusunun yaklaşık \%7,5'ini oluşturmaktadır. Yarı-Parlamenter Sistem de bu kategori altında değerlendirilecektir. 
Şekil 1. Parlamenter Monarşi ile Yönetilen Ülkeler ve Kategorileri

\begin{tabular}{|c|c|c|c|c|c|}
\hline \multicolumn{6}{|c|}{ PARLAMENTER MONARŞİ } \\
\hline \multicolumn{3}{|c|}{ Avrupa } & \multicolumn{3}{|c|}{ Diğer } \\
\hline $\begin{array}{c}\text { Danimarka } \\
\text { Isveç } \\
\text { Norveç }\end{array}$ & $\begin{array}{c}\text { Belçika } \\
\text { İspanya } \\
\text { Andora } \\
\text { Lüksemburg } \\
\text { Hollanda }\end{array}$ & Birleşik Krallık & $\begin{array}{c}\text { Jamaika } \\
\text { Papua Yeni Gine } \\
\text { Solomon Adalart }\end{array}$ & Lesoto & $\begin{array}{c}\text { Kamboçya } \\
\text { Malezya } \\
\text { Tayland }\end{array}$ \\
\hline \multicolumn{2}{|c|}{ Yarı-Parlamenter Monarşi } & \multicolumn{2}{|c|}{ Asya-Pasifik } & \multicolumn{2}{|c|}{ Amerika } \\
\hline $\begin{array}{c}\text { Monako } \\
\text { Lihtenştayn }\end{array}$ & $\begin{array}{l}\text { Kuveyt } \\
\text { Nepal } \\
\text { Urrdün } \\
\text { Fas } \\
\text { Bahreyn }\end{array}$ & $\begin{array}{c}\text { Tuvalu } \\
\text { Yeni Zelanda } \\
\text { Avustralya }\end{array}$ & Japonya & $\begin{array}{l}\text { Antigua ve Barbuda } \\
\text { Bahamalar } \\
\text { Barbados } \\
\text { Belize } \\
\text { Grenada } \\
\text { Saint Lucia } \\
\text { Saint Kitts ve Nevis } \\
\text { Saint Vincent ve } \\
\text { Grenada }\end{array}$ & Kanada \\
\hline
\end{tabular}

\subsubsection{Avrupa}

Ad1 demokrasi de olsa cumhuriyet de olsa, Yunanistan'daki, Roma'daki ve İtalya'daki demokrasi modelleri günümüz modern demokrasinin pek çok karakteristik özelliğinden yoksundu (Dahl, 2010:25). Bu noktada modern demokrasi tohumlarının Kuzey Avrupa ve çevresinde atıldığını söyleyebiliriz. Bu atılan modern demokrasinin tohumları Avrupa' daki parlamenter monarşi sistemlerini incelediğimizde ne kadar önemli ölçüde özgürlüğe katkı sağladığını görebilmekteyiz.

Avrupa kategorisinde toplam 9 ülke bulunmaktadır ve bu kategoriyi 3 alt kategoride incelemekte fayda vardır. Birinci Kategori olan Kuzey Avrupa'da 3 ülke bulunmaktadır ve bu ülkelerin ortalama özgürlük puanı 99'dur. Dünyada özgürlük puan 100 üzerinden 100 olan 5 ülkeden ikisi bu kategoride bulunmaktadır. Bu ülkelerin nüfus ortalaması yaklaşık 7,5 milyon olup kişi başına düşen milli gelir açısından dünyanın önde gelen ülkeleri arasındadırlar. Yine bu ülkelerin her biri ulusal bir tarihe sahip olur üniter bir devlet yapısına sahiptir.

Avrupa kategorisi altındaki diğer kategori olan Güney ve Batı Avrupa kategorisini 5 ülke oluşturmaktadır: Lüksemburg, Hollanda Andora, Belçika ve İspanya. Andora, nüfus ve yüz ölçümü bakımında küçük bir ülke olup İspanya ve Fransa'nın sınırları arasında 13. yüzyıldan bu yana varlığını sürdüren bir krallıktır. Belçika ve İspanya yine ulusal tarihe sahip ülkeler olup nüfusları ve yüzölçümleri Andora'ya kıyasla yüksektir. Bu ülkelerin öne çıkan özelliği şu şekildedir. İspanya Samuel Huntington'ın tabiri ile üçüncü dalga demokrasiye sahip bir ülkedir yani ulusal bir tarihe sahip olmasına rağmen demokratikleşme süreci yakın bir tarihte başlamıştır. Bunu yanı sıra yüksek işsizlik oranı ve ekonomik sıkıntıların yanı sıra yakın geçmişte diktatörlükten demokratik bir sisteme geçmesi olmuştur. Belçika ise yakın bir tarihten bu yanan (1993) federal bir sistemle yönetilmektir. Hem Belçika hem de İspanya Avrupa kıtasında bulunan ülkelere nazaran etnik 
köken, kültür dil ve lehçe bakımından oldukça zengindir. Bu zenginlik devlet yönetimi ve siteminde kendini yüksek ölçüde belli etmektedir. Her iki ülkede de birden fazla resmi dil bulunması ve Belçika' da federal sistem, İspanya' da özerk yönetim talepleri bu zenginliğe örnek teşkil etmektedir.

Avrupa kategorisi altında değerlendirebileceğimiz Birleşik Krallık Parlamenter Monarşi(Westminster) modelinin en büyük temsilcisi olması itibariyle ve dünyada bulunan birçok hükümet sistemine ilham vermesi ile önemli bir yere sahiptir. Freedom House raporuna göre 95 özgürlük puanına sahip Birleşik Krallık 'free' statüsüne sahiptir.

\subsubsection{Amerika}

Amerika kategorisinde toplam 9 ülke bulunmaktadır ve bu kategoriyi 2 alt kategoride incelemekte fayda vardır. Orta Amerika 1'de Karayip ülkeleri de olarak nitelendirebileceğimiz ve parlamenter monarşi ile yönetilen 8 ülke bulunmaktadır. Bu ülkelerin tamamı ada ülkesi olup yüz ölçümleri ve nüfusları bakımından küçük ülkelerdir. Gelirleri büyük ölçüde tarıma ve turizme dayalıdır. Bu ülkeler bağımsızlıklarını yakın geçmiş olarak sayılabilecek 1966-1983 yılları arasında elde etmişler. Saint Kitts ve Nevis federal bir düzene sahipken diğerleri üniter bir devlet yapısına sahiptir.

Bu ülkelerin ortalama özgürlük puanı yaklaşık 90'dır. Freedom House'un raporuna göre her biri free statüsüne sahiptir. Bu ülkeler yakın geçmişteki bağımsızlıkları ve kişi başına düşen düşük milli gelire rağmen bu derece yüksek özgürlük puanına sahip olması büyük ölçüde Commonwealth ülkeleri arasında bulunup, demokratik kültürün, geleneğin ve kurumların bıraktığı miras olarak açıklanabilir.

Amerika kategorisinde Kuzey Amerika ya da Kanada olarak isimlendirebileceğimiz alt kategoride Kanada ele alınmaktadır. 99 gibi yüksek bir özgürlük puanına sahip Kanada, geniş yüzölçümü ve kişi başına düşen yüksek milli gelir ile öne çıkmaktadır. Aynı zamanda bir Commonwealth ülkesi olması sebebiyle gelen demokrasi kültürü Kanada'yı bu denli özgür kılan sebepler olarak belirtilebilir.

\subsubsection{Asya-Pasifik}

Asya-Pasifik kategorisinde toplam 4 ülke bulunmaktadır ve bu kategoriyi 2 alt kategoride incelemekte fayda vardır. Birinci kategori olan Asya-Pasifik 1'de 3 ülke yer almaktadır: Avustralya, Yeni Zelanda ve Tuvalu. Bu ülkelerin özgürlük puanları sırasıyla 98, 98 ve 94'dür. Avustralya ve Yeni Zelanda 20. yüzyılın başlarında bağımsızlıklarını elde ederken Tuvalu 1978 yılında bağımsızlığını elde etmiştir. Bu ülkelerden Avustralya ve Yeni Zelanda'nın uzun bir süre önce bağımsızlıklarını elde etmesinin yanı sıra kişi başına düşen yüksek milli gelir ve Commonwealth ülkeleri arasında bulunup, demokratik kültürün, geleneğin ve kurumların bıraktığ miras bu derece yüksek özgürlük puanına sahip olmasının başlıca nedenleri arasında sayılabilmektedir.

Asya-Pasifik kategorisi altındaki bir diğer ülke Japonya'dır. 99 puan ile dünyada önde gelen özgürlük derecesine sahip ülkelerden biri olan Japonya, köklü ulus geçmişi ve II. Dünya Savaşı sonrası ABD’nin bırakmış olduğu demokrasi mirasının yanı sıra köklü bir ulusal tarihi, güçlü eğitim sitemi ve teknolojideki ilerlemeleriyle öne çıkan bir ülkedir.

\subsubsection{Diğer}

Parlamenter monarşi sistemi her ne kadar Anglo-Sakson kültürüne ait bir hükümet sistemi olarak benimsenmiş olsa da dünyanın geri kalanında da bu hükümet sistemine rastlamak mümkündür. Bu ülkeler diğer başlıklı kategori altında incelenecektir.

Diğer kategorisi alt kategorilerinden biri olan Asya-Pasifik 2 kategorisini 3 ülke oluşturmaktadır: Kamboçya, Malezya ve Tayland. Parlamenter Monarşi sistemindeki en düşük ortalamaya sahip bu kategorinin ülkeleri ortalama 36 özgürlük puanına sahiptir. Kategoride, Kamboçya ve Malezya'nın oldukça fakir ve Japonya'nın 
işgalinden yakın bir tarihte kurtulduğu görülmektedir. Tayland ise coğrafi ve kültürel olarak Çin'e yakınlığ1 Freedom House raporunda kendini göstermiştir.

Bu kategorinin diğer bir alt başlı̆gı olan Orta Amerika 2 alt kategorisinde 3 ülke bulunmaktadır ve ortalama özgürlük puanı 67'dir. Öncelikle Jamaika ele alınacak olursa eğer 'Free' statüsüne sahip olmasına rağmen özgürlük derecesi 75 olduğu görülmektedir. Bu birkaç sebebe dayandırılabilir. Öncelikle Orta Amerika bölgesindeki Commonwealth ülkeleri arasında 3 milyona yakın nüfusuyla en kalabalık ülke Jamaika'dır. Freedom House'un Jamaika özelinde yayınlamış olduğu raporda bürokraside 'yozlaşma' ve 'toplum içinde şiddet' konuları dikkat çekmektedir. Bu durum ülkede -kategori içerisindeki diğer ülkelere nazaran- fazla nüfusla beraber bireysel özgürlükleri kısıtlıyor, yasaların uygulanmasını zorlaştırıyor ve ifade ve inanç özgürlüğüne engel olduğu görülüyor. Yine Papua Yeni Gine, Jamaika gibi bürokraside yozlaşma, aile ve toplum içi şiddet gibi konular ön plana çıkıyor. Bunun yanında istikrarlı bir hükümete sahip olmayışı kategori içerisindeki en düşük skora sahip olmasının nedenleri arasında görülebilir. Solomon Adaları'nda durum ekonomik sebeplerden kaynaklanan hükümetteki istikrarsızlık olarak açıklanabilir.

Partly Free statüsü ile diğer kategorisinin bir diğer alt başlığını oluşturan Lesoto 1966 yılında bağımsızlığını kazanmış bir Afrika ülkesidir. 2015 yılında 'Free' statüsüne sahip iken ülkedeki gerçekleşen askeri darbe ve ülkede büyük çaptaki nüfusu etkileyen hastalıklar ülkenin statüsünü düşürmüştür. Bir Afrika ülkesi olmasına rağmen ülkenin ulusal bir tarihe sahip olması ve bir zamanlar Britanya'nın bir kolonisi olmuş olması ülkenin 67 gibi ortalama bir özgürlük puanı elde etmesini sağlayan sebepler arasında gösterilebilir.

\subsubsection{Yart-Parlamenter Monarşi}

Yarı-Anayasal monarşiler Afrika, Avrupa ve Güney Asya'da görülen az sayıdaki bir hükümet sistemidir. YarıParlamenter 1 alt kategorisini oluşturan Lihtenştayn ve Monako Avrupa ile benzer bir kültüre sahip olmasının yanı sıra özgürlük noktasında benzer derece ve skorlara sahiptir. 19. yüzyıl başlarında kurulan bu iki ülkenin nüfusları ve yüzölçümleri oldukça düşük iken ortalama özgürlük puan1 93'dür.

Parlamenter monarşi sisteminin 'model içerisindeki monark, yasama ve yürütme organlarının dengeleyici bir sisteme sahip olması ve bundan dolayı her ne kadar koalisyon hükümetlerine rastlanmasa da uzlaşmacı bir ortam yaratması' özelliğini pek fazla hayata geçiremeyen Yarı-Parlamenter 2 alt kategorisinin ülkeleri her ne kadar adı yarı-anayasal olsa da anayasal boyutuna yeterince yetki vermemektedir. Bu ülkelerin ortalama özgürlük puanı 35 'dir.

\subsection{Parlamenter Sistem}

Parlamenter sistemin özellikleri konusunda literatürde herkes tarafindan kabul edilmiş bir tanım bulunmamaktadır. Ancak hükümet sisteminin “parlamenter” olarak adlandırılması için kabul görülen iki özellik vardır: hükümetin parlamentodan çıkması ve parlamentoya hesap vermesidir (Tunçkaşık, 2015:2). Epstein'e (1968) göre yürütmenin yasama iktidarından (parlamentodan) doğduğu ve ona karşı sorumlu olduğu bir sistemdir. Bu özellik ve tanımın ardından tüm ülkeler için geçerli bir model ortaya konulamamaktadır. Ne kadar parlamenter rejim ile yönetilen ülke varsa o kadar farklı parlamenter sistemi vardır (Alkan, 2013:100).

Parlamenter hükümet sistemini tamamıyla açıklayamasa da şu özellikler önemlidir: i) iki başlı bir yürütme organına sahip olması, ii) siyasi sorumluluğu bulunmayan bir devlet başkanının olması, iii) bakanlar kurulunun siyasi sorumluluğunun bulunması, iv) yasama organının güvenoyu vermesi ve yürütmenin yasamayı fesih etme yetkisinin bulunması (Lijphart, 2006; Teziç, 1998; Özbudun, 2008:297). 
Tablo 2. Parlamenter Sistem ile Yönetilen Ülkeler ve Kategorileri

\begin{tabular}{|c|c|c|}
\hline Kategori & Ülke Sayısı & Ortalama Özgürlük Puanı \\
\hline Balkan Dışı Avrupa & 8 & 94 \\
\hline Balkanlar & 6 & 67 \\
\hline Güney Asya & 4 & 70 \\
\hline Pasifik & 2 & 88 \\
\hline Karayip & 2 & 90 \\
\hline Afrika & 1 & $41(44)$ \\
\hline Ortadoğu & $3(4)$ & 55 \\
\hline
\end{tabular}

Hükümet sistemi olarak parlamenter sistemi benimsemiş ülkeler özgürlük üzerinden değerlendirirken 7 ana kategori halinde ele alınacaktır. Bu 7 kategori içerisinde 26 ülke bulunmakta olup dünya nüfusunun yaklaşık $\% 27,5$ 'ini oluşturmaktadır.

Şekil 2. Parlamenter Sistem ile Yönetilen Ülkeler ve Kategorileri

\begin{tabular}{|c|c|c|c|}
\hline \multicolumn{4}{|c|}{ PARLAMENTER SİSTEM } \\
\hline Balkanlar & Ball & & Güney Asya \\
\hline $\begin{array}{c}\text { Arnavutluk } \\
\text { Bosna-Hersek } \\
\text { Moldova } \\
\text { Macaristan } \\
\text { Yunanistan } \\
\text { Türkiye }\end{array}$ & & & $\begin{array}{l}\text { Bangladeş } \\
\text { Pakistan } \\
\text { Singapur } \\
\text { Hindistan }\end{array}$ \\
\hline Pasifik & Karayip & Afrika & Ortadoğu \\
\hline $\begin{array}{c}\text { Vanuatu } \\
\text { Fiji }\end{array}$ & $\begin{array}{l}\text { Dominika } \\
\text { Trinidad ve Tobago }\end{array}$ & Maritus & $\begin{array}{l}\text { Etiyopya } \\
\text { Irak } \\
\text { Issail } \\
\text { (Türkiye) }\end{array}$ \\
\hline
\end{tabular}

\subsubsection{Balkan Dışı Avrupa}

Parlamenter sistemin en iyi temsilcilerinin bulunduğu Avrupa kategorisinde ortalama 91 özgürlük puanına sahip 8 Avrupa ülkesine bulunmaktadır. Bu ülkelerin kişi başına düşen milli gelirleri yüksek iken nüfus ve yüzölçümü bakımından ideal seviyelerdedir. Demokrasinin doğup yayıldığı bir coğrafya olan Avrupa'da 
bulunması sebebiyle bu ülkeler yüksek özgürlük skorlarına sahip iken yine 100 tam puana sahip San Marino bu kategoride yer almaktadır.

\subsubsection{Balkanlar}

Balkanlar yakın tarihteki gerçekleşen siyasi ve hükümet yapılanmaları ile oldukça yeni bir bölgedir. Bu gelişmeler bölge üzerindeki mevcut ülkelerin demokrasi ve özgürlük derecelerinde de kendini göstermektedir. 53 özgürlük puanı ile Türkiye'de bu kategoride değerlendirilmiştir.

\subsubsection{Güney Asya}

Güney Asya kategorisini 4 ülke oluşturmaktadır. Sahip olduğu nüfus ile dünyada en fazla ikinci ülke olması ile Hindistan önemli bir gösterge niteliği taşımaktadır. Nüfus-özgürlük puanı dengesi bakımından dünyada en pozitif tabloya sahip olan Hindistan, tarihinde derin tecrübeler elde ettiği demokratikleşme süreçleri ve Moore'un tabiriyle İngiltere sömürgesi ardından gelen tepeden inme devrim Hindistan'ın bugünkü demokrasi ve özgürlük derecesini şekillendiren etkenler arasındadır. Diğer yandan yüzyıllardır ülkedeki yolsuzluk, sağlısız kamu yönetimi ve korunamayan insan hakları özgürlük derecesini şekillendiren etkenler arasında belirtilebilir.

Güney Asya kategorisinin diğer 3 ülkesi özgürlük puanı ortalaması bakımından maalesef Hindistan gibi olmayıp, 47'dir. Bangladeş ve Pakistan dünyanın en yoğun nüfusuna sahip ülkelerin başında gelmektedir. Bu ülkelerin Hindistan ile olan tarihsel, kültürel ve coğrafi yakınlığına rağmen farklı statülere sahip olması araştırmanın çarpıcı noktalarından biridir.

\subsubsection{Pasifik}

Pasifikte bulunan bu iki ülkenin ortalama özgürlük puanı 69'dur. Vanuatu free statüsüne sahipken Fiji partly free statüsüne sahiptir. Ülkelerin tarihi ve coğrafi benzerlikleri birbirine oldukça yakındır. Vanuatu'nun Fiji'den nispeten yüksek olması Vanuatu'nun bir zamanlar Fransa-İngiltere sömürü altında olması veya Fiji'nin yoğun göç vermesi sonucu ekonomik durgunluk olarak açıklanabilir.

\subsubsection{Karayip}

Orta Amerika'da az sayıdaki parlamenter sisteme sahip ülkelerden ikisi olan Dominika ve Trinidad ve Tobago ortalama 88 özgürlük puanına sahiptir. 1960 sonrası bağımsızlığını kazanan bu ülkeler klasik Karayip ülkeleridir.

\subsubsection{Afrika}

Birçok ulus ve grubun yönetimi altında bulunan Maritus 1968 yılında bağımsızlığını elde etmiştir. 90 özgürlük puanı ile bölgesinde dikkat çekici bir niteliğe sahiptir.

\subsubsection{Ortadoğu}

$\mathrm{Bu}$ kategoriyi oluşturan ve kategorinin en düşün özgürlük puanlarına sahip Etiyopya ve Irak, parlamenter sistemin en kötü temsilcilerinden... Her iki ülkede de demokratik kurumların ve işleyişsin olmaması not free statüsünde değerlendirilmesini sağlıyor. Ancak bu kategoride değerlendirilebilecek İsrail, yüksek özgürlük puanı ve sahip olduğu uzlaşmacı siyasi kültürle diğer ülkelerden sırırlmaktadır. Balkanların yanı sıra bu kategoriye de uygun niteliklere sahip Türkiye, özgürlük ortalaması yükselten bir etkiye sahiptir.

\subsection{Başkanlık Sistemi}

Başkanlık sistemi, büyük ölçüde Kuzey Avrupa'daki politik düşüncelerden etkilenmiş, parlamenter monarşi hükümet sisteminin damarlarındaki geleneksel yapı sökülüp, ciğerlerine bol bol Amerikan havası sindirilmiş kökleri Avrupa'ya dayanan özgün bir Amerikan ürünüdür (Bezci, 2005:78; Yanık, 1997:19). 
Başkanlık sistemi yasama ve yürütmenin belirgin bir şekilde ayrılması özelliği ile ön plana çıkan bir hükümet sistemidir. Juan. J. Linz'in tabiriyle sistem olarak başkanlık sistemi yasama ve yürütme organlarının karşıtlık prensibi üzerine kurulmuştur (Linz, 1985:3). Ünlü siyaset bilimci Giovanni Sartori’nin tanımı üzerinden başkanlık sisteminin özelliklerini şu şekilde açıklamak mümkündür: i) devlet başkanının belli bir zaman dilimi için doğrudan doğruya ya da ona benzer bir yöntemle halk tarafindan seçilir, ii) hükümetin parlamentonun oyu atanamaz ve düşürülemez, iii) başkanın görev süresinin sabittir, iv) ikili bir otoriteye izin vermeyen yani başkanın atadığı hükümetlere başkanlık ettiği ya da onları yönlendirdiği bir politik sistemdir (Sartori, 1997:110115).

Tablo 3. Başkanlık Sistemi ile Yönetilen Ülkeler ve Kategorileri

\begin{tabular}{|c|c|c|}
\hline Kategori & Ülke Sayısı & Ortalama Özgürlük Puanı \\
\hline Amerika Birleşik Devletleri & 1 & 90 \\
\hline Latin Amerika & 18 & 70 \\
\hline Afrika & 19 & 45 \\
\hline Orta-Batı Asya & 5 & 17 \\
\hline
\end{tabular}

Hükümet sistemi olarak başkanlık sistemini benimsemiş ülkeler özgürlük üzerinden değerlendirirken 4 ana kategori halinde ele alınacaktır. Bu 4 kategori içerisinde 43 ülke bulunmakta olup dünya nüfusunun yaklaşık \%27'sini oluşturmaktadır. Başkanlık sistemi incelenirken bölgede benzer profillere sahip ülkeler olduğu için alt kategoriler oluşturulmamıştır.

Şekil 3. Başkanlık Sistemi ile Yönetilen Ülkeler ve Kategorileri

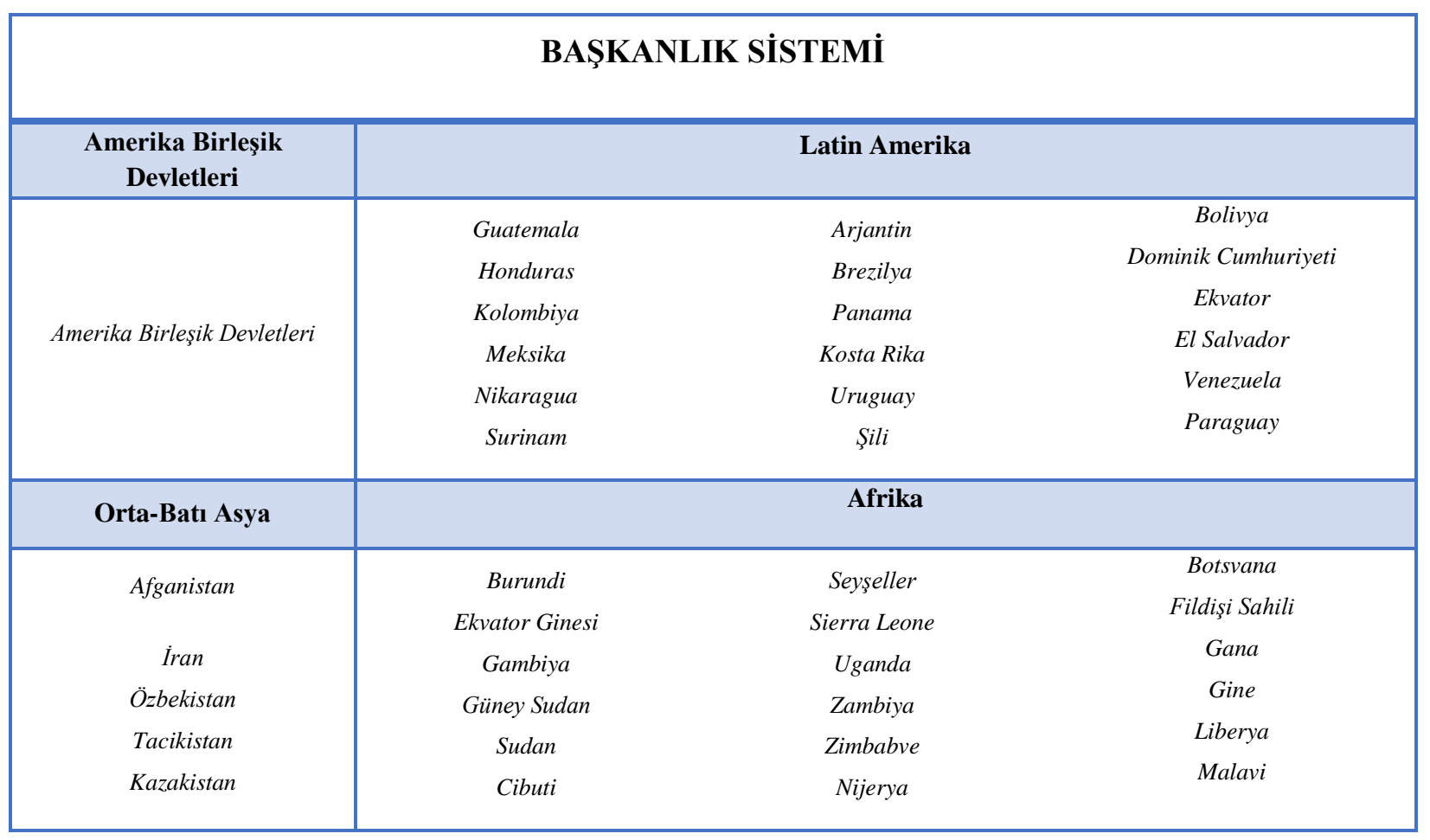




\subsection{1. $\quad$ Amerika Birleşik Devletleri}

Başkanlık sisteminin doğduğu topraklar olan Amerika Birleşik Devletleri, nüfus, milli gelir, yüz ölçümü ve federal yönetim sitemi ile bir kategori şeklinde incelenmesi için makul ölçüde özelliğe sahiptir. Sahip olduğu bu özellikleriyle dünyanın önde gelen ülkelerden biri olması demokrasi puanına da yansımış, Freedom House tarafından yüksek bir puan ile değerlendirilmiştir.

\subsubsection{Latin Amerika}

Yakın tarihleri, kültürleri ve jeopolitik konumları sebebiyle başkanlık sistemine sahip 18 Latin Amerika ülkesi bir kategori altında değerlendirilmiştir. Bu 18 ülkenin ortalama özgürlük puanı 70 olup, 35-98 arası özgürlük puanları arasında ülkelerin oluşturduğu çeşitlilik dikkat çekmektedir. Başkanlık sisteminin tüm olumlu ve olumsuz yönlerini çeşitli değişkenlere rağmen bu 18 ülke tarafindan yansıtılmaktadır.

\subsubsection{Afrika}

Tıpkı Latin Amerika kategorinde olduğu gibi Afrika kıtasında bulunan başkanlık sistemine sahip 19 ülke bir kategori altında toplanmıştır. Bu ülkelerin ortalama özgürlük puanı 41'dir. Benin ve Gana haricinde free statüsüne sahip ülke bulunmamaktadır. Bu kategorideki ülkelerin neredeyse tamamı bağımsızlıklarını 19551990 tarihleri arasında elde etmiş, yine neredeyse tamamının milli gelirleri dünya standartları altındadır.

\subsubsection{Orta-Batı Asya}

Güney Avrasya olarak nitelendirilen kategoride 6 ülke bulunmaktadır. Bu ülkeler tamamı not free statüsünde sahip olup özgürlük puanı ortalaması 15'dir. Kazakistan, Tacikistan ve Türkmenistan 1991 yılında bağımsız bir devlet statüsüne ulaşmışken Afganistan, İran ve Özbekistan ulusal tarihe sahiptir. Bu kategoride de nüfus ve milli gelir gibi değişkenler göze çarpsa da devlet başkanlarının sahip olduğu geniş yetki ve ülkelerdeki birçok demokratik kurumun eksikliği bu kategoriyi başkanlık sisteminin en kötü kategori olarak değerlendirilmesine neden oluyor.

\subsection{Yarı- Başkanlık Sistemi}

Yarı-başkanlık sistemi, Fransa'nın 1962 yılında gerçekleştirdiği anayasa değişikliğiyle, cumhurbaşkanını halk tarafından esasınsın benimsenmesi üzerine, yeni bir model olarak literatürde ve uygulamada yerini almıştır (Yaz1c1, 2013:91).

Duverger'e göre bir hükümet sistemi, şu üç unsuru içeriyorsa yarı-başkanlık olarak kabul edilir: i) başkan veya cumhurbaşkanı halk tarafından seçilmeli, ii) başkan oldukça önemli yetkilere sahip olmalıdır, iii) parlamento ile uyumlu çalışan başbakan ve bakanlar kurulu olmalıdır (Elgie akt. Duverger, 2007).

Tablo 4. Yarı-Başkanlık Sistemi ile Yönetilen Ülkeler ve Kategorileri

\begin{tabular}{|c|c|c|}
\hline Kategori & Ülke Sayısı & Ortalama Özgürlük Puanı \\
\hline Amerika & 3 & 92 \\
\hline Balkanlar Hariç Avrupa & 9 & 75 \\
\hline Balkanlar & 8 & 46 \\
\hline Afrika & 28 & 49 \\
\hline
\end{tabular}




\begin{tabular}{|c|c|c|}
\hline Asya & 7 & 86 \\
\hline Okyanusya & 7 & 85 \\
\hline
\end{tabular}

Yarı-Başkanlık sistemi, tüm hükümet sistemlerinin kesiştiği bir noktada bulunması sebebiyle dünyanın her köşesinde uygulanan bir sistemdir. Yarı-Başkanlık sistemi altında incelenecek ülkeler resmen veya fiilen bu sistemi uygulayabiliyor olabilir. Bu sebeplerden dolayı en çok kategori Yarı-Başkanlık sistemi altında incelenecektir.

Şekil 4. Yarı-Başkanlık Sistemi ile Yönetilen Ülkeler ve Kategorileri

\begin{tabular}{|c|c|c|c|}
\hline \multicolumn{4}{|c|}{ YARI-BAŞKANLIK SİSTEMI } \\
\hline Amerika & Balkanlar Hariç Avrupa & Eski SSCB ve Doğu Bloğu & Balkanlar \\
\hline $\begin{array}{c}\text { Haiti } \\
\text { Peru } \\
\text { Guyana }\end{array}$ & $\begin{array}{c}\text { Fransa } \\
\text { Portekiz } \\
\text { Avusturya } \\
\text { Finlandiya } \\
\text { Irlanda } \\
\text { Izlanda } \\
\text { Polonya } \\
\text { Litvanya } \\
\text { Klbrls }\end{array}$ & $\begin{array}{c}\text { Azerbaycan } \\
\text { Gürcistan } \\
\text { Ermenistan } \\
\text { Beyaz Rusya } \\
\text { Ukrayna } \\
\text { Rusya } \\
\text { Slovakya } \\
\text { Kırgızistan } \\
\text { Moğolistan }\end{array}$ & $\begin{array}{c}\text { Bulgaristan } \\
\text { Hirvatistan } \\
\text { Makedonya } \\
\text { Karadağ } \\
\text { Kosova } \\
\text { Sirbistan } \\
\text { Slovenya } \\
\text { Romanya }\end{array}$ \\
\hline \multicolumn{4}{|c|}{ Afrika } \\
\hline $\begin{array}{c}\text { Cezayir } \\
\text { Angola } \\
\text { Kamerun } \\
\text { Çad } \\
\text { Kongo Cumhuriyeti } \\
\text { Kongo Demokratik } \\
\text { Cumhuriyeti } \\
\text { Misır }\end{array}$ & $\begin{array}{c}\text { Gabon } \\
\text { Ruanda } \\
\text { Yemen } \\
\text { Gine Bissau } \\
\text { Orta Afrika Cumhuriyeti } \\
\text { Burkina Faso } \\
\text { Moritanya }\end{array}$ & $\begin{array}{c}\text { Komorlar } \\
\text { Tanzanya } \\
\text { Mozambik } \\
\text { Kenya } \\
\text { Togo } \\
\text { Madagaskar } \\
\text { Mali }\end{array}$ & $\begin{array}{c}\text { Yeşil Burun Adaları } \\
\text { Senegal } \\
\text { Güney Afrika } \\
\text { Tunus } \\
\text { Sao Tome ve Principe } \\
\text { Namibya } \\
\text { Nijer }\end{array}$ \\
\hline \multicolumn{2}{|c|}{ Asya } & \multicolumn{2}{|c|}{ Okyanusya } \\
\hline & $\begin{array}{l}\text { Kore } \\
\text { an } \\
\text { yler } \\
\text { ler } \\
\text { nka } \\
\text { ezya }\end{array}$ & $\begin{array}{c}M \\
\\
D\end{array}$ & \\
\hline
\end{tabular}




\subsubsection{Amerika}

Amerika kıtasında yaygın olan hükümet sistemi Başkanlık Sistemi olmasına rağmen tıpkı dünyanın geri kalanında olduğu gibi Yarı-Başkanlık sistemi de az da olsa kıtada yer bulmuştur. Haiti, Peru ve Guyana ortalama 62 özgürlük puanına sahiptir.

\subsubsection{Balkan Hariç Avrupa}

Parlamenter sistemdeki performansını Yarı-Başkanlık sisteminde de gösteren Avrupa ülkelerinden 9 ülke 95 ortalama özgürlük puanına sahiptir. Yine 100 tam puana sahip 5 ülkeden 2'si bu kategoride bulunmaktadır.

\subsubsection{Balkanlar}

11 Balkan ülkesinin 8'i Yarı-Başkanlık sistemi ile yönetilmektedir. Kategoride bulunan 4 ülke Avrupa Birliği üyesi olup bu kategorinin ortalama özgürlük puanı 75'dir.

\subsubsection{Eski SSCB ve Doğu Bloğu}

9 ülkenin bulunduğu bu kategoride eski Sovyetler Birliği’nin öncü ülkesi Rusya ve yakın bir tarihe kadar Sovyet etkisinin hissedildiği ülkeler bulunmaktadır. Bu kategorideki ülkelerin devlet başkanları geniş yetkilere sahip olup demokratik bir seçimin gereklilikleri tartışılır durumdadır. Her ne kadar Ukrayna gibi demokratik şartları sağlamaya çalışan Ermenistan ve Gürcistan kategoride yer alsa da özgürlük puanı ortalaması 49 olarak tespit edilmiştir.

\subsubsection{Afrika}

Afrika kıtasındaki ülkelerin büyük çoğunluğunun 21. yüzyılın ikinci yarısı kazanmış olduğu bağımsızlıklar bu kıtadaki ülkelerin hükümet sistemleri de etkilemiştir. Yerleşik bir demokrasi kültürünün olmadığı bölgede özellikle üçüncü dalga demokrasi ülkelerinde yaygın olan yarı-başkanlık sistemi çeşitli boyutlardaki nüfus, milli gelir ve yüz ölçüme sahip 28 ülkenin hükümet sistemi olarak karşımıza çıkmaktadır. Bu ülkelerin 6'sı free 6's1 not free iken geri kalan 16 ülke partly free statüsüne sahiptir. Statülerdeki bu denge kendisini kategorinin 46 ortalama özgürlük puanıyla kendini göstermektedir.

\subsubsection{Okyanusya}

Okyanusya'da oldukça küçük yüzölçümleri ve yakın tarihteki bağımsızlıkları ile dikkat çeken Yarı-Başkanlık sistemine sahip 7 ülke bulunmaktadır. Bu ülkeler 85 özgürlük puanı ortalaması ile dikkat çekmektedir.

\subsubsection{Asya}

Asya kategorisini oluşturan 7 ülke bulunmaktadır. Bu ülkeler 86 ortalama özgürlük puanına sahiptir.

\subsection{Demokratik Kabul Edilmeyen Hükümet Sistemleri}

Robert Dahl (2010:99) demokratik bir ülke için gerçekleşmesi gereken altı kurumun varlığ 1 üzerinde durmuştur: seçimler belirlenmiş memurlar, özgür, adil ve sık sık yapılan seçimler, ifade özgürlüg̈̈̈, alternatif bilgilenme kaynaklart, kurumsal özerklik ve vatandaşların dahil edilmesi. Günümüzde ne yazık ki bu kurumların tamamının ya da bir kısmının bulunmadığı ülkeler mevcuttur. Bu ülkeler, toplumda demokratik bir ortam yaratamamanın yanı sıra özgürlüğü de büyük ölçüde kısıtlamaktadır. Bahsi geçen bu ülkeler genellikle literatürde ve uygulamada meşru görülmeyen şu hükümet sistemlerine sahiptir: Mutlak Monarşi, Tek Partili Rejim, Teokrasi ve Askeri Cunta ve Geçici Hükümet ile yönetilen devletler. 
Tablo 5. Demokratik Kabul Edilmeyen Hükümet Sistemleri, Ülkeleri ve Kategorileri

\begin{tabular}{|c|c|c|}
\hline Kategori & Ülke Sayısı & Ortalama Özgürlük Puanı \\
\hline Mutlak Monarşiler & 8 & 33 \\
\hline Tek Partili Yönetimler & 8 & 9 \\
\hline Belirli Bir Hükümet (Sistemi) Olmayan & 3 & 17 \\
\hline
\end{tabular}

Şekil 5. Demokratik Kabul Edilmeyen Hükümet Sistemleri, Ülkeleri ve Kategorileri

\begin{tabular}{|c|c|c|}
\hline \multicolumn{3}{|c|}{ NOT- FREE SISTEMLER } \\
\hline Mutlak Monarşiler & Tek Partili Yönetim & Belirli Bir Hükümeti Olmayan \\
\hline Bhutan & Çin Halk Cumhuriyeti & \\
Birleşik Arap Emirlikleri & Küba & Libya \\
Brunei & Eritre & Myanmar \\
Katar & Kuzey Kore & Somali \\
Suudi Arabistan & Laos & \\
Umman & Suriye & \\
Svaziland & Türkmenistan & \\
Tonga & Vietnam & \\
\hline
\end{tabular}

\subsubsection{Mutlak Monarşiler}

Bu kategoride ülkeler mutlak monarşi ile yönetilmektedir. Doğal kaynaklarından dolayı oldukça zengin olan bu ülkeler yukarıda belirtildiği gibi demokratik bir ülkenin şartlarını yerine getirmemektedir. Ancak bu noktada ortalama özgürlük puanı 75 olan Tonga'ya ve 56 özgürlük puanına sahip olan Bhutan'a bir parantez açmak gerekir. Bhutan'daki hâkim din ve yaşayış tarzı, Tonga'daki Birleşik Krallığın hâkimiyeti bu ülkeleri mutlak monarşiye rağmen partly free statüsüne sahip bir puan almasını sağlamıştır. Ama buna rağmen kategorinin ortalaması 33 olarak kalmıştır.

\subsubsection{Tek Partili Yönetimler}

Demokratik kurumları ve gereklilikleri ülkelerinde yer vermeyen bu ülkeler araştırma içerindeki en düşük (9) ortalama özgürlük puanına sahip olarak tek partili yönetimlerin ne kadar kabul edilemez olduğunu kanıtlamıştır.

\subsubsection{Belirli Bir Hükümeti Olmayan Ülkeler}

Bu kategorideki 3 ülke bulunmakta olup yönetimleri askeri cunta veya geçiş hükümetlerine aittir.

\section{GENEL DEĞERLENDİRME}

Çalışmada Freedom House'un değerlendirmede bulunduğu -herhangi bir yere bağlı ve tartışmalı bölgeler haricinde- bağımsız 195 ülke 5 hükümet sistemi altında incelenmiştir. Bu 5 hükümet sistemi altında çeşitli kriterlere göre 26 kategori ve bu kategorilere ait alt kategoriler oluşturulmuştur. 
Freedom House'un (2016:20) raporunda da belirttiği gibi 195 ülkenin \%44'ü yani 86 ülke free, \%30'u yani 59 ülke partly free ve geri kalan \%26'sı yani 50 ülke not free olarak değerlendirilmiştir. Bu verileri nüfus açısından ele alırsak eğer yaklaşık 7,5 milyon dünya nüfusunun 3 milyonu (\%40) free, 1,8 milyonu (\%24) partly free ve 2,7 milyonu (\%36) not free statüleri altında yaşamaktadır.

Çalışmada kesin olmamakla beraber en sağlıklı verilere göre 36 ülkenin Parlamenter Monarşi, 26 ülkenin Parlamenter Sistem, 43 ülkenin Başkanlık Sistemi, 71 ülkenin Yarı-Başkanlık Sistemi ve 19 ülkenin demokratik kabul edilmeyen (hükümet) sistemleri ile yönetildiği tespit edilmiştir. Freedom House 2016 raporunun yanı sıra elde edilen veriler ışığında ülkelerin özgürlük statüleri bakımında yüzdesel dağılımı her bir hükümet sistemindeki özgürlük statüleri ile paralel olmadığı saptanmıştır. Yine her statü, özgür, kısmen özgür ve özgür değil, her hükümet sisteminde mevcuttur. Örneğin Demokratik Kabul Edilmeyen ülkeler kategorisinde 75 özgürlük puanına sahip bir ülke bulunurken, özgürlük puanı ortalaması en yüksek hükümet sistemi olan Parlamenter Monarşi kategorisinde 32 özgürlük puanına sahip ülke bulunmaktadır. Bu da hükümet sistemleri ile özgürlüğün arasında kısmen bir ilişkinin olduğunu ortaya koymaktadır (Şekil 6).

Şekil 6. Hükümet Sistemlerine Göre Ülke Sayısı

\begin{tabular}{ll}
\hline 36 & Parlamenter Monarşi \\
\cline { 2 - 2 } & En Düşük Özgürlük Puanı 32 - 100 En Yüksek Özgürlük Puanı \\
\hline 46 & Parlamenter Cumhuriyet Sistemi \\
\hline En Düşük Özgürlük Puanı 15 - 100 En Yüksek Özgürlük Puanı \\
\hline 71 & Başkanlık Sistemi \\
\hline En Düşük Özgürlük Puanı 3 - 98 En Yüksek Özgürlük Puanı \\
\hline 19 & Yarı-Başkanlık Sistemi \\
\hline En Düşük Özgürlük Puanı 7 - 100 En Yüksek Özgürlük Puanı \\
\hline Demokratik Kabul Edilmeyen \\
\hline En Düşük Özgürlük Puanı -1 - 75 En Yüksek Özgürlük Puanı
\end{tabular}

Veriler nüfus bakımından incelendiğinde belirgin ölçüde bir farklılık ortaya çıkmaktadır. Ülkeler noktasında free, partly free ve not free statüsüne sahip ülkelerin yüzdeleri sırasıyla $\% 44, \% 30$ ve $\% 26$ iken, nüfus bakımından incelendiğinde free, partly free ve not free statüleri altında yaşayan dünya nüfusunun yüzdeleri sırasıyla \%39, \%25 ve \%36'dır. Bu tablonun oluşmasında dünya nüfusunun yaklaşık \%20'sini oluşturan not free statüsüne sahip Çin Halk Cumhuriyeti'nin etkisi oldukça fazladır. Diğer yandan 195 ülkeden en düşük nüfusa sahip 30 ülkenin 27'sinin free statüsüne sahip olması ve yine 27'sinin 1950 sonrası bağımsızlığını kazanmış iken bu 30 ülkede tüm hükümet sistemlerinin yer bulmuş olması özgürlük değerlendirmelerinde hükümet sistemlerinin tek etken olmadığını göstermektedir.

Hem nüfus hem de ülke sayıları bazında incelendiğinde Parlamenter Monarşi ve Parlamenter Sisteme sahip ülkelerin özgürlük noktasında diğer hükümet sistemlerine göre daha iyi durumda olduğu \%60'ın üzerindeki yüzdelerle kendini kanıtlamaktadır. Aynı zamanda bu hükümet sistemleri özgürlük noktasında dünya ortalamasının belirgin bir şekilde üzerinde olduğu görülmektedir. Başkanlık Sistemi özgürlük noktasında ülke sayılarına göre kendi içerisinde dengeli bir duruma sahipken dünya ortalamasının biraz gerisinde olduğunu söylemek mümkündür. Dünyada diğer sistemlere göre daha fazla uygulanan Yarı-Başkanlık Sistemi dünya ortalaması ile paralel değerlere sahip olduğu görülmektir. Ancak nüfus noktasında Başkanlık sistemi gibi dünya ortalamasında düşük değerlere sahiptir. Son olarak demokratik kabul edilmeyen hükümet sistemleri ile yönetilen ülkeler dünya ortalamasının oldukça gerisinde kalmıştır. Ülke bazında az sayıda demokratik olmayan 
hükümet sistemi olduğu görülse de nüfus bakımından dünyanın yaklaşık \%23’ü demokratik olarak kabul edilmeyen hükümet sistemleri altında yaşamaktadır.

Tablo 6. Hükümet Sistemleri Kategorilerine Dair Sayısal Veriler

\begin{tabular}{|c|c|c|c|c|c|c|}
\hline \multirow{2}{*}{ No. } & \multirow{2}{*}{ Hükümet Sistemi } & \multicolumn{3}{|c|}{ Freedom House Statüleri } & \multirow{2}{*}{$\begin{array}{l}\text { Kategori } \\
\text { Sayısı }\end{array}$} & \multirow{2}{*}{$\begin{array}{l}\text { Ülke } \\
\text { Sayısı }\end{array}$} \\
\hline & & Free & Partly Free & Not Free & & \\
\hline 1 & Parlamenter Monarşi & 25 & 7 & 4 & 5 & 36 \\
\hline 2 & Parlamenter Sistem & 16 & 8 & 2 & 5 & 26 \\
\hline 3 & Başkanlık Sistemi & 12 & 19 & 12 & 4 & 43 \\
\hline 4 & Yarı-Başkanlık Sistemi & 32 & 24 & 15 & 9 & 71 \\
\hline 5 & $\begin{array}{l}\text { Demokratik Kabul Edilmeyen } \\
\text { Hükümet Sistemleri }\end{array}$ & 1 & 1 & 17 & 3 & 19 \\
\hline & Toplam & 86 & 59 & 50 & 26 & 195 \\
\hline
\end{tabular}

Tablo 7. Hükümet Sistemleri Kategorilerine Dair Yüzdesel Veriler

\begin{tabular}{|c|l|c|c|c|c|}
\hline \multirow{2}{*}{ No. } & \multirow{2}{*}{ Hükümet Sistemi } & \multicolumn{3}{|c|}{ Freedom House Statüleri } & Ülke Sayıs \\
\cline { 2 - 5 } & & Free (\%) & Partly Free (\%) & Not Free (\%) \\
\hline $\mathbf{1}$ & Parlamenter Monarşi & 69,4 & 19,4 & 11,2 & $\mathbf{1 8 , 5}$ \\
\hline $\mathbf{2}$ & Parlamenter Sistem & 64 & 28 & $\mathbf{1 2 , 8}$ \\
\hline $\mathbf{3}$ & Başkanlık Sistemi & 27,3 & 43,2 & 29,5 & $\mathbf{2 2 , 5}$ \\
\hline $\mathbf{4}$ & Yarı-Başkanlık Sistemi & 44,4 & 34,7 & $\mathbf{3 6 , 9}$ \\
\hline $\mathbf{5}$ & $\begin{array}{l}\text { Demokratik Kabul Edilmeyen } \\
\text { Hükümet Sistemleri }\end{array}$ & 5,5 & 5,5 & 89 & $\mathbf{9 , 3}$ \\
\hline & Toplam & $\mathbf{4 4}$ & $\mathbf{3 0}$ & $\mathbf{2 6}$ & $\mathbf{1 9 5}$ \\
\hline
\end{tabular}

Hükümet sistemleri ile özgürlük arasında doğrudan bir bağlantı kurmak doğru değildir. Bu noktada çalışmada oluşturulan alt kategoriler önem arz etmektedir. Bulgular kısmındaki tablolar üzerinden alt kategoriler incelendiğinde en yüksek ortalamaların Avrupa alt kategorilerine ait olduğu görülmektedir. Demokrasinin doğup geliştiği bölgeler 195 ülke arasında en yüksek özgürlük puanlarına sahip ülkeler olarak bulgular arasında yer almaktadır. Yine yüksek puanlara sahip kategoriler arasında Anglo-Sakson kültürünün etkisinin olduğu ülkelerin varlığı göze çarpmaktadır. Jeopolitik konum açısından da güvenli ve tehlike tehdidi olmayan özellikle küçük ada ülkelerinin yüksek özgürlük puanlarına sahip olduğu görülmektedir.

Avrupa'da demokratik olmayan rejim bulunmamaktadır. Bu durum Küba istisnası haricinde Amerika kıtası için de geçerlidir. Amerika, Avrupa'dan sonra başkanlık sisteminin doğduğu topraklar olması itibariyle önemli bir yere sahiptir. Bunun yanında Başkanlık Sistemini uzlaşmacı kültürü ile birleştiren ve birleştiremeyen Latin Amerika ülkeleri ile yüksek özgürlük puanlarının yer aldığı bir bölgedir. 
Tablo 8. Hükümet Sistemlerinin Nüfuslarına Dair Sayısal Veriler

\begin{tabular}{|c|c|c|c|c|c|}
\hline \multirow{2}{*}{ No. } & \multirow{2}{*}{ Hükümet Sistemi } & \multicolumn{3}{|c|}{ Nüfus } & \multirow{2}{*}{ Toplam } \\
\hline & & Free $(M)$ & Partly Free (M) & Not Free $(M)$ & \\
\hline 1 & Parlamenter Monarşi & 356 & 108 & 93 & 558 \\
\hline 2 & Parlamenter Sistem & 1.525 & 373 & 139 & 2.037 \\
\hline 3 & Başkanlık Sistemi & 656 & 569 & 285 & 1.510 \\
\hline 4 & Yarı-Başkanlık Sistemi & 378 & 767 & 496 & 1.642 \\
\hline 5 & $\begin{array}{l}\text { Demokratik Kabul Edilmeyen } \\
\text { Hükümet Sistemleri }\end{array}$ & 0.1 & 0.7 & 1.666 & 1.667 \\
\hline & Toplam & 2.915 & 1.819 & 2.680 & 7.500 \\
\hline
\end{tabular}

Tablo 9. Hükümet Sistemleri Nüfuslarına Dair Yüzdesel Veriler

\begin{tabular}{|c|c|c|c|c|c|}
\hline \multirow{2}{*}{ No. } & \multirow{2}{*}{ Hükümet Sistemi } & \multicolumn{3}{|c|}{ Nüfus } & \multirow{2}{*}{ Ülke Sayıs } \\
\hline & & Free (\%) & Partly Free(\%) & Not Free(\%) & \\
\hline 1 & Parlamenter Monarşi & 4,80 & 1,47 & 1,26 & 7,52 \\
\hline 2 & Parlamenter Sistem & 20,56 & 5,03 & 1,88 & 27,47 \\
\hline 3 & Başkanlık Sistemi & 8,85 & 7,68 & 3,85 & 20,37 \\
\hline 4 & Yarı-Başkanlık Sistemi & 5,11 & 10,35 & 6,69 & 22,15 \\
\hline 5 & $\begin{array}{l}\text { Demokratik Kabul Edilmeyen } \\
\text { Hükümet Sistemleri }\end{array}$ & 0,01 & 0,01 & 22,47 & 22,48 \\
\hline & Toplam & 39,32 & 24,54 & 36,14 & 100 \\
\hline
\end{tabular}

Yine çalışma boyunca oluşturulan alt kategoriler incelendiğinde bir alt kategoriyi ortalama 5 ülkenin oluşturulduğu görülmektedir. Bu durumu nüfus, kişi başına düşen milli gelir, yönetim sistemi, yüz ölçümü, bağımsızlık yılı, Anglo-Sakson kültürü, jeopolitik konum gibi bir değişkenlerin yarattığı yaklaşık 40 farklı hükümet sistemi özgürlük ilişkisi bulunduğu gösterir. Avrupa, Latin Amerika ve Afrika büyük ölçüde bir karakter edinmiş bölgeler haricinde dünyanın her bölgesinde -kısmen Avrupa, Latin Amerika ve Afrika dâhilfarklı özgürlük puanı ve hükümet sistemi ile karşılaşılabilir. Bu noktada özgürlüğü yalnız hükümet sistemleri ile değerlendirmek sağlıklı bir değerlendirme olmayacaktır. Ancak hükümet sistemlerinin özgürlük üzerinde hiçbir etkisinin de bulunmadığı doğru değildir. Elde edilen istatistikler ve veriler bu durumu kanıtlar niteliktedir. 


\section{Grafik 1. Nüfus ve Ülkelere Göre Özgürlük Statülerinin Dağılımı}

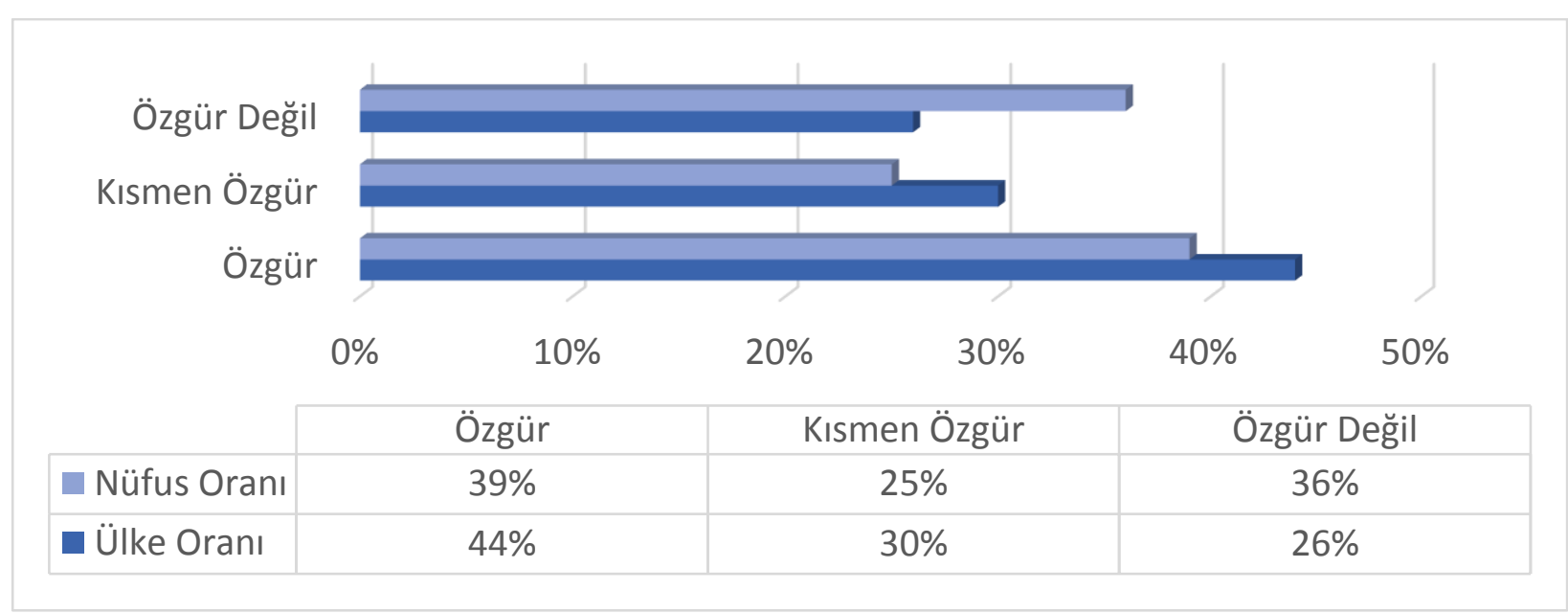

Hükümet sistemlerinin özgürlük üzerindeki kısmen etkisinden bahsettikten sonra şunu da belirtmekte fayda vardır. Arend Lijphart, parti sistemleri, seçim sistemleri, anayasaları, yönetim sistemleri, nüfusları, ekonomik durumları ve Merkez Bankaları gibi birçok değişkenle incelediği 36 ülke sonrasında çoğunlukçu demokrasilerden ziyade uzlaşmacı demokrasilerin daha fazla demokrasi vaat ettiği sonucuna varmıştır.

Avrupa'nın yanı sıra İsviçre, İsrail, Japonya, Hindistan, Moğolistan ve Başkanlık Sistemine sahip uzlaşmacı kültüre sahip Latin Amerika ülkelerinde olduğu gözlemlenen yüksek özgürlük puanları değişkenler her ne olursa olsun uzlaşmacı yapıya sahip bir hükümet sisteminin daha fazla özgürlük vaat ettiği sonucuna varabiliriz.

\section{TÜRKIYY İÇIN DEĞERLENDIRME}

2007 yılında Cumhurbaşkanı'nın halk tarafından seçilmesini öngören anayasa değişikliğinden itibaren Türkiye'nin fiili olarak literatürde ve uygulamada örneğine nadir rastlanan bir şekilde yarı-başkanlık sistemi ile yönetildiğini söylemek mümkündür. 53 özgürlük puanı ile partly free statüsüne sahip Türkiye, 8 . Cumhurbaşkanı Turgut Özal'dan bugüne kadar Başkanlık Sistemi tartışmalarına şahit olmuştur ve nihayetinde 16 Nisan 2017 tarihinde yapılan referandum ile yeni ve özgün bir hükümet sistemine, Cumhurbaşkanlığı Hükümet Sistemine, kavuşmuştur. Jeopolitik konumu, ulusal tarihi, nüfus yapısı ile özel bir konuma sahip olan Türkiye'yi çalışmada oluşturulmuş herhangi bir kategori veya alt kategoriye koymak oldukça zordur. Dünya tarihinde önemli bir geçmişe sahip Türkiye'nin 20. yüzyıldaki tecrübe ettiği ulusal ve uluslararası gelişmeler Türkiye'yi gelişmekte olan bir ülkenin ötesine taşımasına izin vermemiş olsa da son yıllarda gelişmiş bir ülke olma adına önemli gelişmeler yaşanmaktadır. Yeni hükümet sistemi geçiş bu gelişmelerin istikrarını sağlamak adına önemli görülmektedir.

Türkiye'nin özel durumunu Freedom House verileri de kanıtlar niteliktedir. Ulusal tarihi, jeopolitik konumu, siyasi kültürü, hükümet sistemi ve nüfusu noktasında eş değer veya bu değerlere yakın bir ülke tespit edilememiştir. Her sistemin avantajları ve dezavantajları arasında büyük bir fark yoktur, bunu araştırma verileri de desteklemektedir. Dünyanın her yerinde ve derin farklı değişkenlere sahip benzer hükümet sistemlerinin varlığı aşikârdır. Osmanlı'nın parlak yıllarındaki kamu yönetimi, coğrafi olarak yakınındaki Avrupa'nın siyasi kültürü, nüfusunun dinamikliği ve doğu-batı kültürleriyle harmanlanmış her hükümet sistemi modeli Türkiye'yi daha fazla özgür kılabilir.

Tüm bu veriler, değerlendirmeler ve 1950 yılında gizli oy, açık tasnif yönteminin kullanıldığı Türkiye Cumhuriyeti'nin ilk demokratik seçiminden bu yana Türk halkının siyasi tercihlerinin çok fazla değişiklik göstermediği gerçeği ışı̆̆ında yüksek özgürlük puanına sahip ülkelerin kurumları ve sistemleri kopyalanıp, içerisi Türk gelenekleriyle doldurulmuş bir hükümet sistemi makul görülebilir. 
Türkiye'nin literatüre ve uygulamaya kazandırdığı yeni Cumhurbaşkanlığı Hükümet Sistemi modeli ve model tartışmaları etrafında şekillenen bu çalışma, hükümet sistemi değişikliği tartışmalarına, hükümet sistemleri ile ilgili modellere ve modellerle ilgili problemlere 1 şık tutan bir çalışma olarak değerlendirilmesi ve faydalanılması bakımından özgün bir çalışma olarak literatüre katkı sağlayacaktır.

\section{KAYNAKÇA}

Alkan, Haluk. (2013) Karşılaştırmalı Siyaset Başkanlık ve Parlamenter Sistemler Işı̆̆ında Yarı Başkanlık Modelleri. Aç1lım Kitap, İstanbul

Bezci, Bünyamin. (2005) "Demokrasi ve Başkanlık Sistemi”" http://acikerisim.lib.comu.edu.tr:8080/xmlui/bitstream/handle/COMU/560/B\%C3\%BCnyamin_Bezci_Makal e.pdf?sequence=1\&isAllowed=y (Erişim Tarihi: 10.09.2016). Yönetim Bilimleri Dergisi 3:2 ss.77-91

Dahl, Robert. (2010) Demokrasi Üzerine Çevirisi Betül Kadıŏ̆lu Phoenix Yayınları, Ankara

Duverger, Maurice (1980) “A New Political System Model: Semi-presidential Government,” European Journal of Political Research 8

Eroğul, C., (2012) Çağdaş Devlet Düzenleri. İmaj Yayınevi, Ankara

Erdem, Kasım. (2014) "Yarı Başkanlık Sistemi: Teori, Pratik ve Tartışmalar” Karşılaştırmalı Hükümet Sistemleri Yarı Başkanlık Sistemi.

Elgie, Robert (2007) "Varieties of Semi-Presentializm and Their Impact on Nascent Democracies" Taiwan Journal of Democracy Cilt 3, Say1 2 http://doras.dcu.ie/4515/2/053-072-Elgie.pdf (Erişim Tarihi: 29.09.2016)

Countries in the World by Population (2016) http://www.worldometers.info/world-population/population-bycountry/ (Erişim Tarihi: 01.09.2016)

Freedom House (2016) Freedom in the World 2016: Anxious Dictators, Wavering Democracies: Global

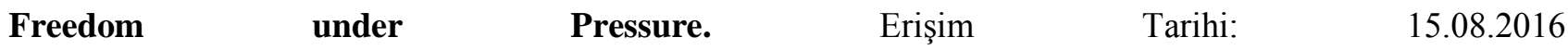
https://freedomhouse.org/sites/default/files/FH_FITW_Report_2016.pdf

Jaggers, Keith ve Ted Robert Gurr. (1995) Polıty III: Regıme Change And Political Authority, 1800-1994. 2nd Icpsr Version. Boulder http://www.icpsr.umich.edu/icpsrweb/ICPSR/studies/6695 (Erişim Tarihi: 30.09.2016)

International Monetary Fund GDP by Country (Erişim Tarihi: 01.09.2016) http://statisticstimes.com/economy/countries-by-projected-gdp.php

Karasu, K., (2009) “İngiltere’de Kamu Yönetimi” Kamu Yönetimi İncelemeleri İmge Kitapevi, Ankara

Land Area by Country. http://world.bymap.org/LandArea.html (Erişim Tarihi: 01.09.2016)

Leon D. Epstein, (1968) Parliamentary Government, International Encyclopedia of the Social Sciences,(ed.David L.Sills), Macmillian and Free Press, New York

Lijphart, Arend. (2006) Demokrasi Motifleri. Çevirisi Ayas, Güneş ve Bulsun, Utku Umut. Salyangoz Yayınları, İstanbul 
Linz, J. Juan. (1985) Democracy: Presendential or Parlamentary Does It Make a Difference? http://pdf.usaid.gov/pdf_docs/PNABJ524.pdf (Erişim Tarihi: 15.09.2016)

Özbudun, Ergun (2008) Türk Anayasa Hukuku Yetkin Yayınevi, İstanbul

Sartori, Giovanni. (1997). Karşılaştırmalı Anayasa Mühendisliği Çevirisi Ergun Özbudun. Yetkin Yayınları, Ankara

Teziç, Erdoğan. (1998) Anayasa Hukuku. Beta Yayınları, İstanbul

Tunçkaşı1k, Halit. (2015) "Parlamenter Sistem: Teori, Pratik ve Tartışmalar" Karşılaştırmalı Hükümet Sistemleri. TBMM Araştırma Merkezi Yayınları, Ankara

Türk Dil Kurumu (2016) “özgürlük” (ErişimTarihi:10.09.2016)

http://www.tdk.gov.tr/index.php?option=com_bts\&view=bts\&kategori1=veritbn\&kelimesec=252961

Yanık, Murat. (1997) Başkanlık Sistemi ve Türkiye’de Uygulanabilirliği, Alfa Yayınları, İstanbul

Yazıcı, Serap. (2013) Başkanlık ve Yarı Başkanlık Sistemleri Türkiye için Bir Değerlendirme. 3. Baskı. İstanbul Bilgi Üniversitesi Yayınları, İstanbul 